J. Dairy Sci. 99:7679-7689

http://dx.doi.org/10.3168/jds.2016-10848

(C) 2016, THE AUTHORS. Published by FASS and Elsevier Inc. on behalf

of the American Dairy Science Association ${ }^{\circledR}$. This is an open access article under

the CC BY-NC-ND license (http://creativecommons.org/licenses/by-nc-nd/3.0/).

\title{
Preparation and stability of milk somatic cell reference materials ${ }^{1}$
}

\author{
Larissa Di Marzo, Karen L. Wojciechowski, and David M. Barbano ${ }^{2}$ \\ Northeast Dairy Food Research Center, Department of Food Science, Cornell University, Ithaca, NY 14853
}

\begin{abstract}
Our objectives were to develop a method to produce milk somatic cell count (SCC) reference materials for calibration of electronic somatic cell count (ESCC) using gravity separation and to determine the effect of refrigerated storage $\left(4^{\circ} \mathrm{C}\right)$ and freeze-thaw stability of the skim and whole milk SCC reference materials. Whole raw milk was high-temperature short-time pasteurized and split into 2 portions. One portion was gravity separated at $4^{\circ} \mathrm{C}$ for $22 \mathrm{~h}$ and the second portion was centrifugally separated to produce skim milk that was also gravity separated with somatic cells rising to the surface. After $22 \mathrm{~h}$, stock solutions (low SCC skim milk, high SCC skim milk, high SCC whole milk) were prepared and preserved (bronopol). Two experiments were conducted, one to compare the shelf-life of skim and whole milk SCC standards at $4^{\circ} \mathrm{C}$ and one to determine the effect of freezing and thawing on SCC standards. Both experiments were replicated 3 times. Gravity separation was an effective approach to isolate and concentrate somatic cells from bovine milk and redistribute them in a skim or whole milk matrix to create a set of reference materials with a wider and more uniformly distributed range of SCC than current calibration sets. The liquid SCC reference materials stored using the common industry practice at $4^{\circ} \mathrm{C}$ were stable (i.e., fit for purpose, no large decrease in SCC) for a 2-wk period, whereas frozen and thawed reference materials may have a much longer useful life. A gradual decrease occurred in residual difference in ESCC (SCC $\times 1,000 / \mathrm{mL}$ ) versus original assigned reference SCC over duration of refrigerated storage for both skim and whole milk SCC samples, indicating that milk ESCC of the preserved milks was gradually decreasing during $28 \mathrm{~d}$ of storage at $4^{\circ} \mathrm{C}$ by about $15,000 \mathrm{SCC} / \mathrm{mL}$.
\end{abstract}

\footnotetext{
Received January 3, 2016.

Accepted April 30, 2016.

${ }^{1}$ Use of names, names of ingredients, and identification of specific models of equipment is for scientific clarity and does not constitute any endorsement of product by authors, Cornell University.

${ }^{2}$ Corresponding author: dmb37@cornell.edu
}

No difference in the ESCC for skim milk was detected between refrigerated and frozen storage, whereas for whole milk the ESCC for frozen was lower than refrigerated samples. Future work is needed to determine the time and temperature of longer term frozen storage over which the SCC results are stable.

Key words: gravity separation, somatic cell, reference materials

\section{INTRODUCTION}

Milk SCC is an indicator of udder health of lactating cows (Schukken et al., 2003). When the bacteria enter the mammary gland and an infection is established, inflammation occurs and white cells from the bloodstream migrate to the mammary gland to combat the infection, leading to an altered (i.e., changes in the volume and composition of milk) secretory function (Jain, 1979; Craven and Williams, 1985; Harmon, 1994). In a healthy cow, milk SCC is normally $<100,000$ cells $/ \mathrm{mL}$. A SCC greater than 200,000 cells/mL indicates that inflammation may be present in the udder (National Mastitis Council, 2001). Milk SCC is also a basis for a portion of the payment for milk to dairy farmers in the United States and provides an incentive to reduce SCC levels (van Asseldonk et al., 2010). An elevated SCC negatively affects farm profitability, and the main economic consequences are caused by treatment, milk production loses, product quality, culling, veterinary services, and the risk of other diseases (Halasa et al., 2007).

Different techniques are used to determine somatic cell levels in milk. They are divided into direct method: direct microscopy (DMSCC) developed by Prescott and Breed (1910), and indirect methods: California mastitis test developed by Schalm and Noorlander (1957) and later standardized by Schneider and Jasper (1964), Wisconsin mastitis test developed by Thompson and Postle (1964), and electronic analyzers (ESCC) described by Madsen (1975). The DMSCC is the validated reference methodology for SCC in milk (Fitts and Laird, 2004: method number 10.010). Electronic analyzers are used to simplify monitoring and measure- 
ment of milk SCC on large numbers of samples (Silveira et al., 2005).

Electronic somatic cell counters are based on different analysis principles, such as the Coulter Counter, in which electrical impulses generated by the passage of particles between 2 electrodes are counted (Mattern et al., 1957; Read et al., 1967), and the optical fluorescence. In the latter method (AOAC International, 2000; method 17.13.01; 978.26), the DNA of cells is stained with a fluorescent dye and when the dye-DNA complex is stimulated by a light source of one wavelength, then the dye-DNA complex emits fluorescence at another wavelength and that is measured and correlated with reference SCC data (Schmidt-Madsen, 1975).

Different organizations use milk SCC data for different purposes. The 3 primary organizations in the United States that produce and use milk SCC data are the National Dairy Herd Improvement Association (NDHIA), the Food and Drug Administration (FDA), and the USDA Federal Milk Markets. In addition, the European Union (EU) has separate standards that are also relevant, particularly in the context of international trade.

The NDHIA in the United States has the objective of promoting accuracy, credibility, and uniformity of NDHIA records, represents the NDHIA system on issues involving other national and international organizations, and organizes industry activities that benefit members (NDHIA, 2013, 2014). The NDHIA SCC program helps the dairy farmer monitor subclinical mastitis status of individual cows using the SCC data to make decisions (i.e., cow segregation, milking order, culling, and so on) and also provides to the farmer a report of current and previous SCC history of individual cows, permitting evaluation of the success or failure of the herd's mastitis control program (NDHIA, 2002). The NDHIA considers SCC normal when it is $<100,000$ cells/mL (NDHIA, 2014).

The goal of the FDA Pasteurized Milk Ordinance (PMO) is to ensure the safety of grade A milk and milk products. The PMO is controlled by the National Conference of Interstate Milk Shipments, which is directed by the US Department of Health and Human Services, Public Health Service, FDA. The FDA has regional milk specialists all around the United States to help the states have consistency in the inspections of bulk tank somatic cell count (BTSCC) of the grade A milk shipments (IDFA, 2013). The maximum legal BTSCC for grade A milk of an individual producer outlined by PMO is 750,000 cells $/ \mathrm{mL}$. If a producer sells milk with the BTSCC value over the limit, a notice is issued and additional samples are tested within $3 \mathrm{wk}$. If in 5 consecutive mo, 3 counts exceed the maximum, the producer may have the permission to sell grade A milk suspended or may have to pay a monetary penalty (FDA, 2013).

The Federal Milk Market Administrators (FMMA) of the USDA laboratories were implemented to validate testing accuracy to ensure fair and equitable payment among producers and processors for milk through the use of Standard Procedures and Official Methods (USDA, 2009). Four of these FMMA-USDA orders also incorporated a per hundredweight adjustment based on the SCC of producer milk (USDA, 2013). The quality adjustment is added to the price if the somatic cell count is below 350,000 cells $/ \mathrm{mL}$ and subtracted from the price if above this value (USDA, 2011a; Code of Federal Regulations, 2015).

The dairy market in EU is regulated by the Common Market Organization for milk and milk products through the Common Agricultural Policy, which has the objective to support raw milk and dairy product prices, and the incomes of dairy farmers (European Commission, 2011). The BTSCC limit for milk established by the EU is 400,000 cells/mL for each individual farm. A geometric mean BTSCC is calculated based on the last 3 mo of BTSCC data, and if it exceeds the legal limit the herd is placed on a watch list and is removed from it only if the next 3 tests are within the limit established. If the geometric mean BTSCC is above the limit for all 3 additional tests, then the herd cannot market milk until corrective action is taken (EUR-Lex, 2004; USDA, 2011b).

The EU and the 3 US organizations described above have some common and some different individual needs regarding analytical accuracy and operational procedures for controlling and validation of the accuracy of milk SCC testing for payment. A common need is the agreement on calibration of the instruments done with a set of certified SCC reference materials with a consistent matrix and range of concentration. An example of a different need is the need in the USDA-FMMA to have accurate SCC across the range of test values because a payment value is determined at each 1,000 SCC above or below 350,000 SCC per mL versus the FDA-PMO system that only needs to correctly classify if the milk from a farm is greater than or less than 750,000 SCC. Thus, the needs for analytical performance (i.e., repeatability and reproducibility) of the reference procedures and the rapid analytical measures are different for the 2 programs due the difference in the use of SCC data. No set of certified reference materials for calibration of ESCC is available (Orlandini, 2012) because the shelf-life of the materials is too short. Typically commercial sets of milk SCC standards in the United States contain 4 different milks because of the amount of work to assemble different milks with different SCC over the desired range and to run a large 
number of direct microscope SCC. From a statistical analysis perspective, 4 levels of SCC across the range from 100,000 to $1,000,000$ SCC are not robust for a linear regression of adjustment of slope and intercept. The use of 4 samples for calibration of ESCC is linked to the requirement in the FDA 2400 form requirements for SCC for the Interstate Milk Shippers (IMS) program and is designed to specifically meet the needs of the IMS program, not other sectors of the industry. Typically for milk component payment testing, 8 or more samples are used to decrease uncertainty and increase accuracy of adjustment of slope and intercept by having a more uniform distribution of levels within the range to avoid high leverage samples, as explained by Kaylegian et al. (2006). The use of milk SCC in payment systems and as a public health criterion for international trade is increasing. More effective approaches are needed to produce high quality reference materials for calibration of ESCC instruments (IDF, 2013) that consist of somatic cells from milk dispersed in a milk matrix.

The objectives of our study were to develop a method based on gravity separation of milk SCC to produce an improved set of milk SCC reference materials for calibration of ESCC and to determine the effect of refrigerated storage $\left(4^{\circ} \mathrm{C}\right)$ and freeze-thaw stability of skim and whole milk reference materials. The improved set would have a wide range of SCC with a uniform distribution across the range, a longer shelf life (i.e., frozen), and would require less time and cost for reference chemistry to produce the set of samples, while meeting diverse needs of various government and industry programs.

\section{MATERIALS AND METHODS}

\section{Experimental Design}

The study was split into 2 separate experiments. In each experiment, both skim and whole milk SCC reference materials were produced by the same manufacturing procedures. The goal of experiment 1 was to determine if the observed SCC of the skim or whole milk SCC reference materials changed with time of refrigerated storage. The goal of experiment 2 was to determine if the observed ESCC of the skim or whole milk SCC reference materials was influenced by frozen storage and thawing before ESCC. Each experiment was replicated 3 times.

\section{Preparation of Somatic Cell Stock Solutions}

A procedure was developed to make milk SCC reference materials for calibration of electronic somatic cell counters. The key innovation was the use gravity separation to produce a naturally occurring high and low
SCC milk. Previous research (Caplan et al., 2013; Geer and Barbano, 2014a,b) has demonstrated that gravity separation causes somatic cells to rise to the top of columns of milk and the somatic cells concentrate in the upper $10 \%$ of the column of milk. This process has the advantage that the somatic cells are somatic cells from milk and the process of isolation of the cells is very gentle and minimizes disruption of somatic cells. The goal of the 2-d process was to produce 3 ingredients: a cream with high SCC and high fat content, a skim milk with low SCC, and a skim milk with high SCC.

On d 1, one batch of whole raw milk (340 kg) was HTST pasteurized (model 080-S, AGC Engineering, Manassas, VA) at $72^{\circ} \mathrm{C}$ for $16 \mathrm{~s}$ and separated into 2 portions (Figure 1). One portion $(170 \mathrm{~kg})$ was gravity separated in a cone bottom tank at $4^{\circ} \mathrm{C}$ for $22 \mathrm{~h}$ and the second portion $(170 \mathrm{~kg})$ was centrifugally separated using a cream separator (model 372 Airtight, DeLaval Separator Co., Poughkeepsie, NY) at $4^{\circ} \mathrm{C}$ to produce skim milk. That skim milk from the centrifugal cream separation of whole milk was also gravity separated in a cone bottom tank at $4^{\circ} \mathrm{C}$ for $22 \mathrm{~h}$.

On d 2, there were 2 tanks of gravity separated milk, one whole milk and one skim milk (Figure 1). Ninety percent of the weight of whole milk was collected out the bottom of the cone tank as a reduced fat milk (about $2.2 \%$ fat) and then the top $10 \%$ of weight in the tank (i.e., gravity cream portion) was collected from the bottom of the cone bottom tank in 5 equal portions. The 5 portions varied in fat and SCC from top to bottom, as described by Caplan et al. (2013) and Geer and Barbano (2014a,b), and the fat and SCC were determined. The reduced fat milk (i.e., lower 90\%) was run through a cream separator (model 372 Airtight, DeLaval Separator Co., Poughkeepsie, NY) producing 2 products: a low SCC cream that was discarded and a skim milk that was used as a low SCC skim milk stock solution containing about $0.1 \%$ fat. Of the 5 equal upper (total $10 \%$ by weight) cream fractions, selected fractions of the high SCC cream and low SCC skim milk were combined to make high SCC whole milk stock solution that had a target level of SCC to achieve the high end of the range of SCC and fat in the whole milk SCC set of reference samples.

For the skim milk, the bottom $90 \%$ of weight of the gravity separated skim milk was collected from the bottom of the second cone tank as a second low SCC skim milk stock solution (about $0.1 \%$ fat) and then the top portion (10\% by weight) of the gravity-separated skim milk was collected in 5 equal portions as the high SCC skim milk containing about $0.25 \%$ fat, using a similar approach as described above for whole milk. Selected fractions of the high SCC skim milk (upper 10\%) and low SCC skim milk were combined to make a high SCC 
skim milk stock solution that had a target level of SCC to achieve the high end of the range of SCC in the skim milk SCC set of reference samples. In both sample series (whole milk and skim), the low SCC stock was sample 1 and the high stock was sample 12. Weight/ weight blends of the 2 stock solutions were made to produce samples 2 to 11 in each set.

\section{Experiment 1: Refrigerated Shelf Life of Skim and Whole Milk Reference Materials}

Preparation of Stock Solutions and Reference Materials. On d 2, 5 layers were collected in equal portions from the top ( $10 \%$ by weight) of both whole milk and skim milk cone bottom gravity separation tanks and analyzed to determine SCC and fat content (Figure 1). The SCC was determined (method 978.26; AOAC International, 2000) using fluorescence flow cytometry (SomaScope, Delta Instruments B.V., Drachten, the Netherlands). The fat content was determined (method 972.16; AOAC International 2000) using a Fourier-transform infrared dairy analyzer (LactoScope FTIR, Delta Instruments B.V.). Based on the SCC and fat content, low and high SCC stock solutions were formulated. For the formulation of the high SCC skim milk stock solution, the high SCC skim milk and the low SCC skim milk stock solution containing about $0.1 \%$ fat were combined (Figure 1). The high SCC whole milk stock solution was formulated using the high SCC gravity separated cream and the low SCC skim milk stock solution containing about $0.1 \%$ fat (Figure 1). The final SCC of the high SCC skim and whole milk stock solutions ranged from 1 million to 1.3 million somatic cells per $\mathrm{mL}$ across replicates. Bronopol was added as a preservative $(0.01 \%$ mass mass; Barbano et al., 2010), and samples of the 2 high

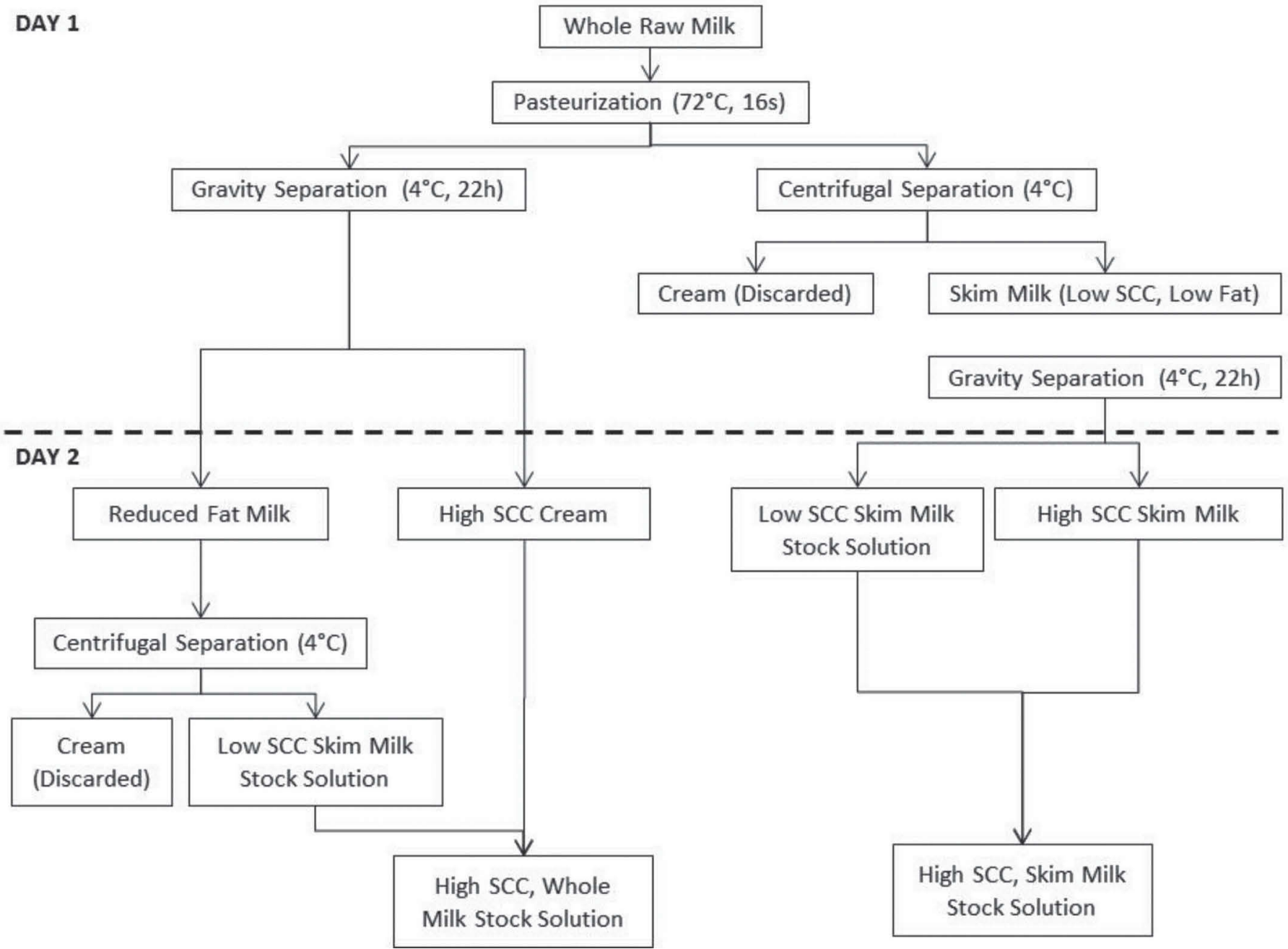

Figure 1. Flow diagram of the preparation method for SCC stock solutions used to produce skim and whole milk SCC reference materials. 
SCC stock solutions and the low SCC skim milk stock solution were sent to 2 external regulatory laboratories for DMSCC (method number 10.010; Fitts and Laird, 2004) to establish reference values for the stock solutions. Typically these regulatory laboratories have several analysts make duplicate DMSCC sample counts of each sample and report the mean value. The analysts that conducted the DMSCC were trained and certified to conduct DMSCC under the FDA IMS program. The mean values from the DMSCC for each stock solution and the weights of the solutions used to formulate each of the 12 milks within the whole and skim milk sample sets were used to calculate a SCC reference value for each of the 12 samples within the whole and skim milk sample sets.

On d 3, sets containing 12 milk dilutions of the high SCC skim milk and separate sets of high SCC whole milk were made (mass/mass) using combinations of the 2 high SCC stock solutions with low SCC skim milk stock solution. The goal within the skim and whole milk set was to achieve a range of SCC in the 12 milks from $<50,000$ to about 1,000,000 SCC per $\mathrm{mL}$, in samples 1 to 12, respectively. Milks were placed in $60-\mathrm{mL}$ sterile sample vials (catalog number CPP02CL, Capitol Plastic Products, Amsterdam, NY). The production of sets of SCC reference materials was done 3 times in different weeks starting from a different batch of milk within experiment 1 and then again within experiment 2 of our study. Within each replicate, 27 sets of 12 samples each of skim milk and whole milk reference materials were produced.

Refrigerated Shelf-Life. Two regulatory laboratories were asked to analyze 8 sets of skim and 8 sets of whole milk SCC reference materials containing 12 samples each, by ESCC spaced out over a 4-wk period. Both laboratories used a Foss-o-matic FC (Foss Electric, Hillerød, Denmark) electronic somatic cell counters with the same methods and staining reagents. Samples were stored at $4^{\circ} \mathrm{C}$. The skim and whole milk reference sets were not used to calibrate the instruments in the 2 laboratories. They were tested as validation samples using their normal calibration of the ESCC in each of the laboratories. The experiment was replicated 3 times starting with a new batch of raw milk each time.

Statistical Analysis. Data were analyzed with the PROC GLM procedures of SAS (version 8.02, 2011, SAS Institute Inc., Cary, NC). A split-plot ANOVA model was used to determine the effect of laboratory, sample (1 to 12), duration of storage ( $4 \mathrm{wk}$ ), and replicate on the observed ESCC of each set. Laboratory, sample, and replicate were treated as categorical whole-plot variables. The error term for the whole-plot variables was laboratory $\times$ sample $\times$ replicate. Ad- ditionally, duration of storage (i.e., time at $4^{\circ} \mathrm{C}$ ) was treated as a continuous sub-plot variable in the model. To determine if significant differences $(P<0.05)$ had occurred in ESCC over time with refrigerated storage for each set, the following full model was used: ESCC $=$ laboratory + sample + replicate + laboratory $\times$ sample + laboratory $\times$ replicate + sample $\times$ replicate + laboratory $\times$ sample $\times$ replicate + time + time $\times$ laboratory + time $\times$ sample + time $\times$ replicate + time $\times$ laboratory $\times$ sample + time $\times$ laboratory $\times$ replicate + time $\times$ sample $\times$ replicate + time $\times$ time + time $\times$ time $\times$ laboratory + time $\times$ time $\times$ sample + time $\times$ time $\times$ replicate + time $\times$ time $\times$ laboratory $\times$ sample + time $\times$ time $\times$ laboratory $\times$ replicate + time $\times$ time $\times$ sample $\times$ replicate + error. Duration of storage (i.e., time) was transformed to mean center the variable as follows: time $=$ actual number of days on storage - [(total days on storage on last day of analysis - total days on storage on first day of analysis)/2]. The transformation minimized the distortion of the ANOVA model due to multicollinearity and made the data set orthogonal in relation to time (Glantz and Slinker, $2001)$. If the $F$-test for the model was significant $(P<$ $0.05)$, the significance of individual terms in the model was reviewed. Terms that were not significant $(P>$ 0.05 ) were removed from the model individually in a stepwise procedure starting with the interaction terms in the sub-plot, until all terms that were not significant were removed from the sub-plot.

Calculation of Residual Difference in ESCC and Mean Residual Difference in ESCC. Residual plots were used to visualize and analyze the data. Residual differences in ESCC of each sample i, averaged across all days $\mathrm{j}$ and replicates $\mathrm{l}$, for each laboratory $\mathrm{k}$, were calculated as follows: residual difference in ESCC $=($ average ESCC sample i, laboratory $\mathrm{k})$ - (average ESCC sample $\mathrm{i}$ across all laboratories), where $\mathrm{i}=$ sample $1,2, \ldots 12, \mathrm{j}=\mathrm{d} 4,7,8,9,11,14,16,18,21,23$, $24,25,28$, where $\mathrm{k}=$ laboratory 1 or 2 and $\mathrm{l}=$ replicate 1,2 , or 3 .

The total mean differences in ESCC by sample, per day, for all laboratories, all replicates, for the skim milk and whole milk sets were calculated as follows: mean residual difference in $\mathrm{ESCC}=$ mean (residual difference in ESCC sample $\mathrm{i}$, day $\mathrm{j}$, laboratory $\mathrm{k}$, replicate 1 ), where $\mathrm{i}=$ sample $1,2, \ldots 12, \mathrm{j}=\mathrm{d} 4,7,8,9$, $11,14,16,18,21,23,24,25,28$, where $\mathrm{k}=$ laboratory 1 or 2 and $l=$ replicate 1,2 , or 3 . Residual difference in ESCC of each sample for each time (days on storage) was calculated by: residual difference in $\mathrm{ESCC}=(\mathrm{av}-$ erage ESCC sample i, day j) - (average ESCC sample $\mathrm{i}$ across all times) for each sample within laboratory $\mathrm{k}$, replicate 1 . 


\section{Experiment 2: Freeze-Thaw Stability of SCC Reference Materials}

Preparation of Stock Solutions and Reference Materials. Skim and whole milk SCC reference materials were prepared as described for experiment 1 . On d 3, a set of 12 milk dilutions of the high SCC skim milk and high SCC whole milk were made (mass/mass) using combinations of the high SCC stock solutions with low SCC skim milk. The range of SCC was from 0 to $1,150,000 \mathrm{SCC} / \mathrm{mL}$ for the high $\mathrm{SCC}$ skim milk sets, and from 0 to $800,000 \mathrm{SCC} / \mathrm{mL}$ for the high $\mathrm{SCC}$ whole milk sets. Half of the sets were stored at $4^{\circ} \mathrm{C}$ and the other half were rapidly frozen in a $-80^{\circ} \mathrm{C}$ freezer (REVCO, Ultima II, model ULT1786-9-D36, Kendro Laboratory Products, Ashville, NC) for $24 \mathrm{~h}$, and then moved to a $-20^{\circ} \mathrm{C}$ freezer for storage. In routine practice, the samples would be frozen using liquid nitrogen or dry ice.

Frozen Shelf-Life. On each day of analysis, one set of skim milk and one set of whole milk refrigerated and frozen milks were tested, using flow cytometry technology, by 2 different laboratories, one using (4',6-diamidino-2-phenylindole) DAPI (SomaScope, Delta Instruments B.V.) and the other using ethidium bromide (Foss-o-Matic FC, Foss Electric) as the dye reagent. The use of 2 different FDA-approved hardware and dye systems was done in experiment 2 to determine if freezing and thawing of samples produced any major effect on the results of one system versus the other. No effects that were dye specific were detected. Preliminary work was done with overnight slow thawing of frozen milks at $4^{\circ} \mathrm{C}$. When slowed thawed samples were placed in the $40^{\circ} \mathrm{C}$ water bath before ESCC analysis, the protein dispersion was not stable and showed clumps of denatured protein, and in whole milks a tendency for oiling off was found. Thus, slow thawing was not used. Refrigerated and frozen samples were shipped to each laboratory in separate containers immediately after preparation. This was done so that the frozen samples would be received in their frozen state at each laboratory. The receiving laboratory stored the unfrozen samples at $4^{\circ} \mathrm{C}$ and frozen samples at $-20^{\circ} \mathrm{C}$ until analysis. On the test day, one set of refrigerated and one set of the frozen samples were put in the water bath at the same time and were analyzed when their temperature reached 40 to $42^{\circ} \mathrm{C}$ on each of the 4 different test days in each laboratory during the 2-wk period.

Statistical Analysis. Data were analyzed with the PROC GLM procedures of SAS (version 8.02, 2011, SAS Institute Inc.). A split-plot ANOVA model was used to determine the effect of laboratory, sample (1 to 12), frozen and refrigerated storage, and replicate on the observed ESCC of each set. Laboratory, sample, and replicate were treated as categorical whole-plot variables. To determine if significant differences $(P$ $<0.05)$ had occurred in ESCC over time with frozen and refrigerated storage for each set, the following full model was used: ESCC $=$ instrument + sample + replicate + frozen + instrument $\times$ sample + instrument $\times$ replicate + instrument $\times$ frozen + sample $\times$ replicate + sample $\times$ frozen + replicate $\times$ frozen + instrument $\times$ sample $\times$ replicate + instrument $\times$ sample $\times$ frozen + sample $\times$ replicate $\times$ frozen + replicate $\times$ frozen $\times$ instrument + instrument $\times$ sample $\times$ replicate $\times$ frozen + error.

\section{RESULTS AND DISCUSSION}

\section{Experiment 1: Refrigerated Shelf Life Stability of SCC Standards}

ESCC for Skim Milk and Whole Milk Sets. The ESCC for the individual samples within the skim milk and whole milk sets, averaged across all treatments and duration of storage, are shown in Table 1 . The range of ESCC was from 5,000 to 1,069,000 SCC/mL for the skim milk set, and from 8,000 to 1,133,000 SCC/mL for the whole milk set (Table 1).

Effect of Laboratory, Sample, Replicate, and Time of $4^{\circ} \mathrm{C}$ Storage on ESCC of Skim Milk and Whole Milks. No effect of laboratory $(P>0.05)$ on the mean ESCC of the skim or whole milk set was detected among the 2 laboratories (Table 2). The mean values for ESCC for laboratories 1 and 2 are shown for the skim and whole milk sample sets (Table 3). A large effect due to sample (Table 2) on SCC was expected because the 12 samples within each set were formulated to have different SCC.

A laboratory by sample interaction $(P<0.05)$ was found for both the skim and whole milk sets (Table 2). The residual differences in ESCC plotted as a function of sample number, averaged across all replicates within each laboratory, for the skim milk and the whole milk sets during $28 \mathrm{~d}$ of refrigerated storage are shown in Figures $2 \mathrm{a}$ and $2 \mathrm{~b}$, respectively. The average residual difference in ESCC decreased as sample number increased within set for laboratory 2 , and the averaged residual SCC increased as sample increased for laboratory 1 in both the skim and whole milk sets (Figure 2). For skim milk set (Figure 2a), the regression equations for laboratory 1 and 2 are as follows: $\mathrm{y}=1.70 \mathrm{x}-8.77$ and $\mathrm{y}=-1.70 \mathrm{x}+8.77$, respectively. For whole milk set the regression equations for laboratory 1 and 2 are as follows: $\mathrm{y}=1.57 \mathrm{x}-7.86$ and $\mathrm{y}=-1.57 \mathrm{x}+7.86$, respectively. The difference in the slope for both the skim and whole milk sets between the 2 laboratories was due to the slope setting in the calibration equa- 
Table 1. Mean electronic somatic cell count (ESCC) for skim milk and whole milk reference sample sets for experiments 1 and 2 averaged across all treatments and times of storage

\begin{tabular}{|c|c|c|c|c|}
\hline \multirow[b]{2}{*}{ Sample } & \multicolumn{2}{|c|}{ Experiment 1} & \multicolumn{2}{|c|}{ Experiment 2} \\
\hline & $\begin{array}{c}\text { Skim milk } \\
\left(\times 10^{3} \mathrm{SCC} / \mathrm{mL}\right)\end{array}$ & $\begin{array}{c}\text { Whole milk } \\
\left(\times 10^{3} \mathrm{SCC} / \mathrm{mL}\right)\end{array}$ & $\begin{array}{c}\text { Skim milk } \\
\left(\times 10^{3} \mathrm{SCC} / \mathrm{mL}\right)\end{array}$ & $\begin{array}{c}\text { Whole milk } \\
\left(\times 10^{3} \mathrm{SCC} / \mathrm{mL}\right)\end{array}$ \\
\hline 1 & 5 & 8 & 5 & 5 \\
\hline 2 & 102 & 104 & 103 & 74 \\
\hline 3 & 197 & 207 & 200 & 145 \\
\hline 4 & 293 & 302 & 295 & 210 \\
\hline 5 & 390 & 404 & 385 & 277 \\
\hline 6 & 486 & 507 & 479 & 345 \\
\hline 7 & 581 & 604 & 573 & 411 \\
\hline 8 & 680 & 707 & 653 & 476 \\
\hline 9 & 780 & 807 & 737 & 542 \\
\hline 10 & 880 & 909 & 826 & 608 \\
\hline 11 & 976 & 1,012 & 914 & 665 \\
\hline 12 & 1,069 & 1,133 & 1,003 & 723 \\
\hline Mean & 537 & 559 & 514 & 373 \\
\hline
\end{tabular}

tion being used within instrument (Figure 2) and was independent of set type. Clearly, these 2 instruments did not differ on average ESCC for the set (Table 3), but they did differ at the high and low ends of the SCC range in both the skim and whole milk sets and is supported by the significant laboratory $\times$ sample interaction in Table 2. Even though the instruments agreed on average, the difference at the high and low ends of the SCC range can lead to an incorrect payment of producers. A recent study reported a similar pattern for milk fat and protein determined using a mid-infrared spectrophotometer (Adams and Barbano, 2015).

A gradual decrease $(P<0.05)$ was found in residual difference in SCC over time of refrigerated storage for both skim and whole milk sets (Figure 3a and 3b, respectively). The mean residual difference ESCC of the set of samples decreased with duration of storage at $4^{\circ} \mathrm{C}$ increased over a 24 -d period, with a mean decrease

Table 2. Type III sum of squares (SS) and probability values for the split-plot ANOVA model to determine the effect of laboratory, sample (1 to 12$)$, replicate $(\mathrm{n}=3)$, and duration of storage (i.e., time in days) at $4^{\circ} \mathrm{C}$ on electronic somatic cell count (ESCC) of skim and whole milk SCC reference materials for experiment 1

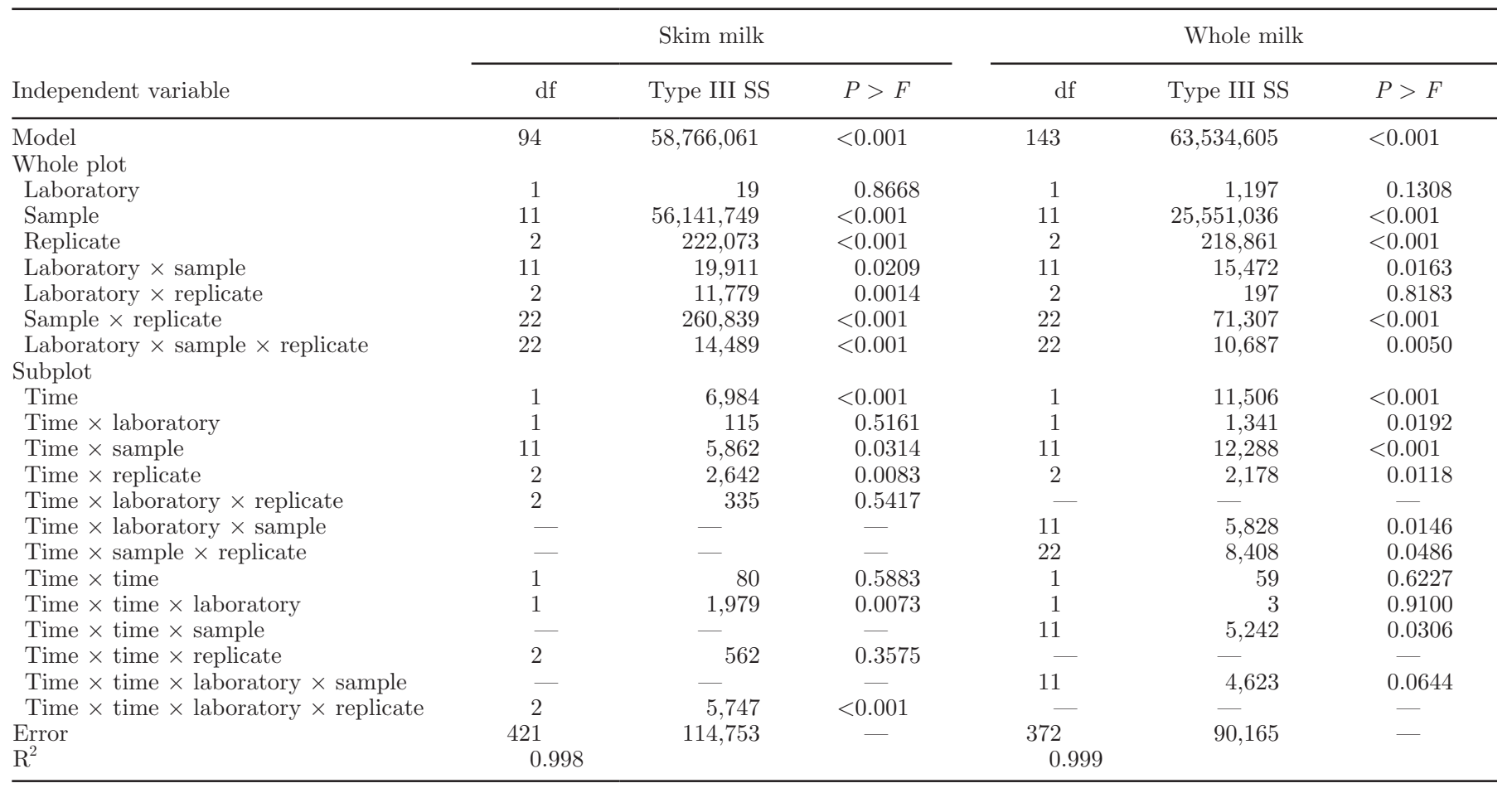


Table 3. Least squares means electronic somatic cell count $(\mathrm{ESCC} \times$ $1,000)$ for skim and whole milk SCC reference materials stored at $4^{\circ} \mathrm{C}$ for 2 different laboratories (experiment 1 and 2) and for refrigerated versus frozen storage (experiment 2) for sets of skim and whole milk $\mathrm{SCC}$ reference materials

\begin{tabular}{lcccccc}
\hline & \multicolumn{2}{c}{ Experiment 1 } & & \multicolumn{2}{c}{ Experiment 2 } \\
\cline { 2 - 3 } \cline { 5 - 6 } Item & Skim milk & Whole milk & & Skim milk & Whole milk \\
\hline Laboratory & 536 & 562 & & $511^{\mathrm{b}}$ & $374^{\mathrm{a}}$ \\
1 & 531 & 557 & & $521^{\mathrm{a}}$ & $372^{\mathrm{b}}$ \\
2 & - & - & & 516 & $376^{\mathrm{a}}$ \\
Frozen & - & - & & 516 & $370^{\mathrm{b}}$ \\
No & & - & - & &
\end{tabular}

${ }^{\mathrm{a}, \mathrm{b}}$ Means in the same column not sharing a common superscript are different $(P<0.05)$.
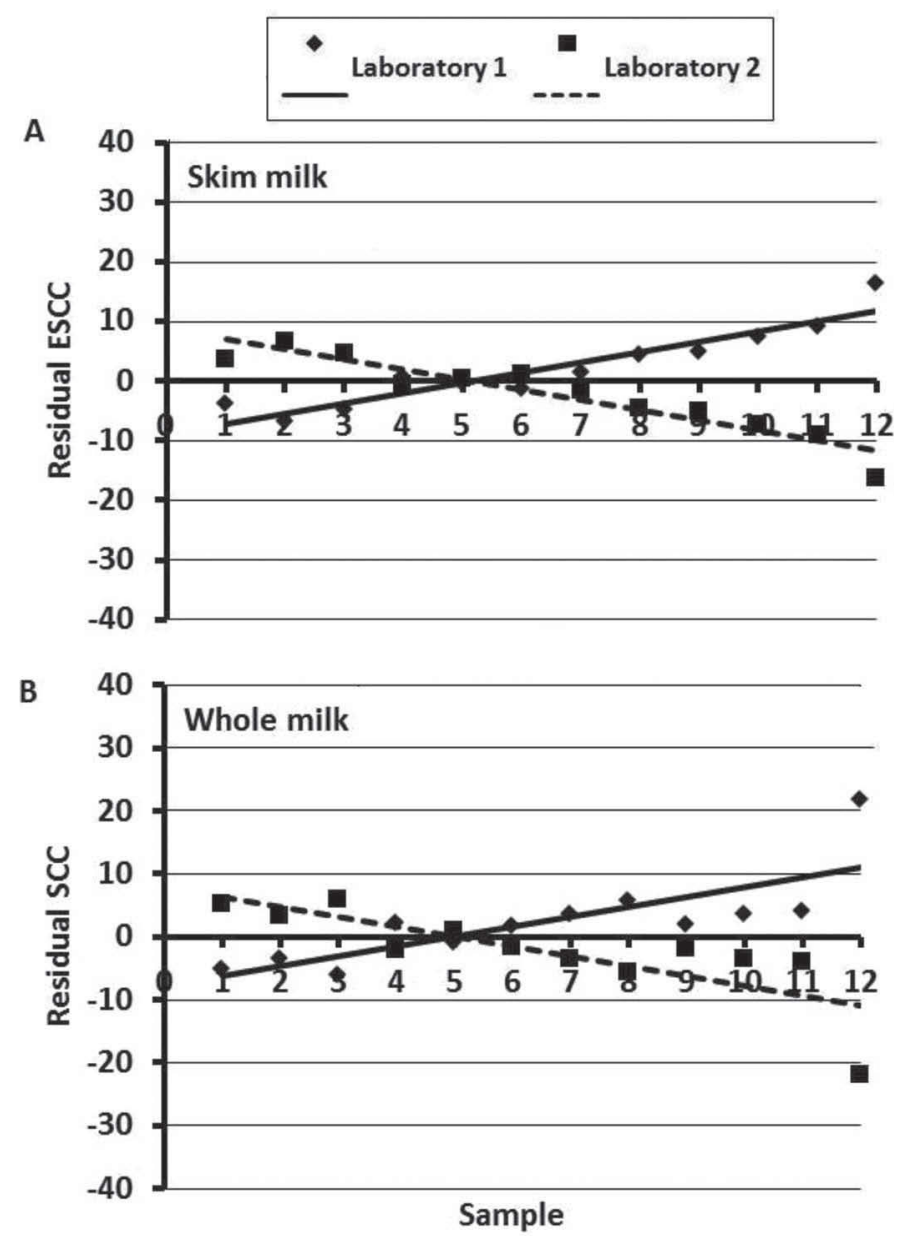

Figure 2. Residual difference in milk electronic SCC $(\mathrm{SCC} \times$ $1,000 / \mathrm{mL} ; \mathrm{ESCC}$ ) for each sample (1 to 12 ), averaged across all replicates for each laboratory (1 and 2), for (A) skim milk at $4^{\circ} \mathrm{C}$ and (B) whole milk at $4^{\circ} \mathrm{C}$ over $24 \mathrm{~d}$ of analysis $\left(28 \mathrm{~d}\right.$ of $4^{\circ} \mathrm{C}$ storage) in experiment 1 .
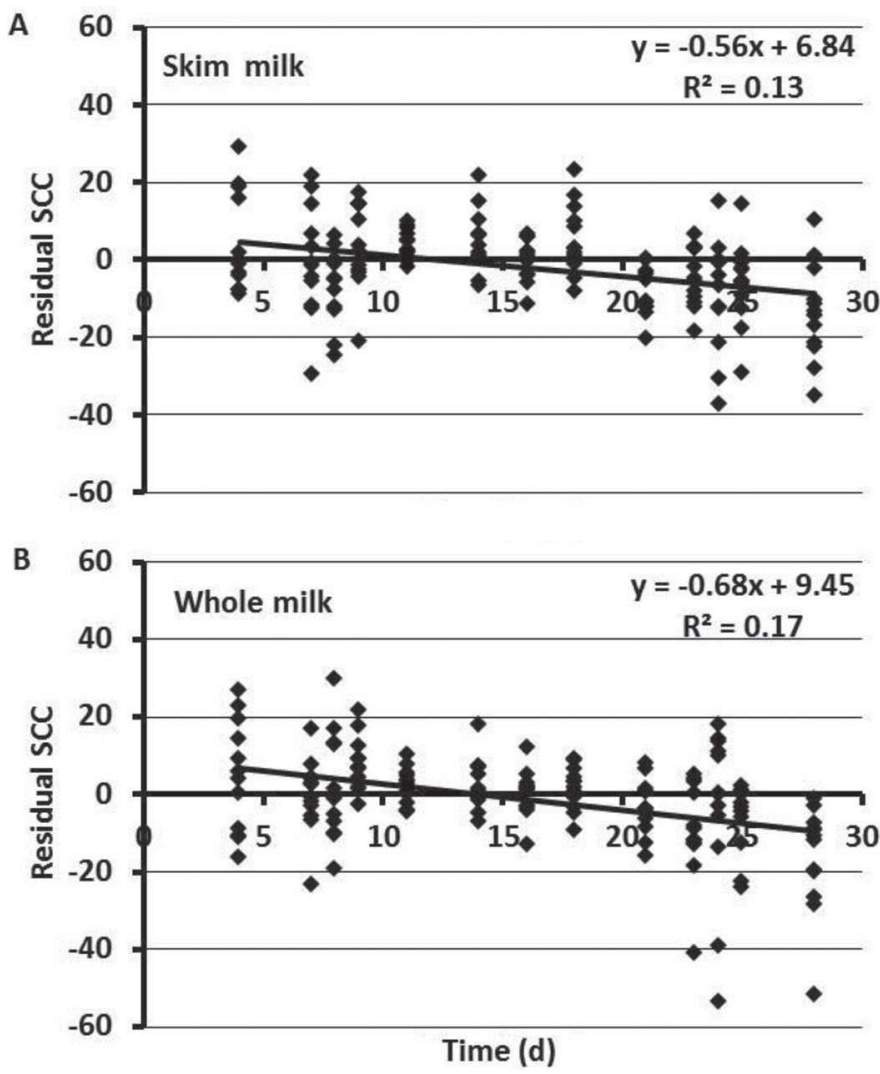

Figure 3. Change in mean residual electronic SCC difference (SCC $\times 1,000 / \mathrm{mL})$ over an interval $\left(28 \mathrm{~d}\right.$ of $4^{\circ} \mathrm{C}$ duration of storage) for $(\mathrm{A})$ skim milk and (B) whole milk in experiment 1.

in ESCC of 13,400 and 16,400 cells per $\mathrm{mL}$ over 28 $\mathrm{d}$ of $4^{\circ} \mathrm{C}$ storage, for the skim and whole milk sets, respectively. The slopes of the regression equations are -0.56 and -0.68 for the skim and whole milk sets, respectively (Figure 3). No interaction $(P>0.05)$ between duration of storage and laboratory for skim milk set was detected, whereas the whole milk set had an interaction $(P<0.05)$ between duration of storage and laboratory (Table 2).

An interaction $(P<0.05)$ was found between duration of storage and sample (Table 2), indicating a difference in the change of ESCC readings over time for both skim milk and whole milk sets that differed as a function of sample number within set. When examining the changes of mean ESCC on a sampleby-sample basis (data not shown), it was clear that samples with higher ESCC (i.e., higher sample number within set) decreased in ESCC more than samples with low ESCC). This was more pronounced in the whole milk set than in the skim milk set. Thus, the changes in ESCC with duration of storage were less for the skim than the whole milk set. Based on the results of experiment 1 , the following question was raised: Is it possible 
Table 4. Type III sum of squares (SS) and probability values for the split plot ANOVA model to determine the effect of laboratory (Delta vs. Foss-o-matic), sample, replicate, and refrigerated versus frozen storage on electronic somatic cell count (ESCC) of skim and whole milk SCC reference materials for experiment 2

\begin{tabular}{|c|c|c|c|c|c|c|}
\hline Independent variable & \multicolumn{3}{|c|}{ Skim milk } & \multicolumn{3}{|c|}{ Whole milk } \\
\hline Model & 95 & $56,922,165$ & $<0.001$ & 84 & $29,830,900$ & $<0.001$ \\
\hline \multicolumn{7}{|l|}{ Whole plot } \\
\hline $\begin{array}{l}\text { Laboratory } \\
\text { Sample }\end{array}$ & 1 & $\begin{array}{r}14,937 \\
56.461786\end{array}$ & $\begin{array}{l}<0.001 \\
<0.001\end{array}$ & 11 & $\begin{array}{r}846 \\
29604.908\end{array}$ & $\begin{array}{r}0.0044 \\
<0.001\end{array}$ \\
\hline Replicate & 2 & 227,185 & $<0.001$ & 2 & 120,467 & $<0.001$ \\
\hline Laboratory $\times$ replicate & 2 & 54,334 & $<0.001$ & 2 & 34,088 & $<0.001$ \\
\hline Laboratory $\times$ frozen & 1 & 5,337 & $<0.001$ & 1 & 515 & 0.0260 \\
\hline Sample $\times$ replicate & 22 & 98,213 & $<0.001$ & 22 & 39,095 & $<0.001$ \\
\hline Sample $\times$ frozen & 11 & 989 & 0.9230 & 11 & 2,400 & 0.0182 \\
\hline Laboratory $\times$ sample $\times$ replicate & 22 & 15,707 & $<0.001$ & 22 & 12,906 & $<0.001$ \\
\hline Laboratory $\times$ sample $\times$ frozen & 11 & 5,586 & 0.0028 & - & - & - \\
\hline Error & 480 & 92,324 & - & 491 & 50,713 & - \\
\hline
\end{tabular}

to eliminate the decrease on ESCC over duration of storage (i.e., extend the shelf life) of the skim milk and whole milk reference material sets by freezing the reference samples, holding them frozen, and then thawing the samples immediately before use?

\section{Experiment 2: Freeze-Thaw Stability of SCC Standards}

ESCC for Skim Milk and Whole Milk Sets. The ESCC for the skim and whole milk sets, averaged across all treatments and times of storage at $-20^{\circ} \mathrm{C}$, are shown in Table 1. The range of SCC was from 5,000 to $1,003,000 \mathrm{SCC} / \mathrm{mL}$ for the skim milk set, and from 5,000 to $723,000 \mathrm{SCC} / \mathrm{mL}$ for the whole milk set (Table 1 ). Our goal was to create sets of reference materials with a wide range of SCC with 12 incremental levels of SCC distributed evenly from low to high across the range. In experiment 2 versus 1 , the whole milk set had a lower mean SCC (Table 1) than the skim milk set. This was done intentionally to try to reduce the amount of vegetative bacteria cells and spores in the highest SCC standards in the whole milk set. The top (10\% weight) was collected in 5 equal portions, but as a standard procedure in the production of the set, the layer containing the higher SCC was not used to avoid high bacteria and spores (Caplan et al., 2013; Geer and Barbano, 2014a,b), leading to a whole milk set with lower mean SCC than the skim milk set (Table 1). The range of SCC of the whole milk set covers the range up to approximately the maximum allowed SCC for grade A milk that is specified in the $\mathrm{PMO}$ with sample number 12 being about 750,000 SCC/mL (FDA, 2013).
Laboratory, Sample, Replicate, and Refrigerated Versus Frozen Storage. An effect of laboratory $(P<0.05)$ on the mean ESCC of the skim and whole milk sets was detected, indicating the presence of differences in the average ESCC readings for both sets among the 2 laboratories (Table 4), but the absolute magnitude of the differences was small (Table 3), as seen from the mean values for ESCC for laboratories 1 and 2 for the skim and whole milk sample sets.

No difference $(P>0.05)$ in the ESCC for skim milk was detected between refrigerated and frozen storage, whereas for whole milk the ESCC for frozen was lower $(P<0.05)$ than refrigerated samples (Table 3 and 4$)$. An interaction $(P<0.05)$ was found between laboratory and sample (Table 4) for both skim and whole milk, indicating a difference in the change in mean residual difference in ESCC for each sample (1 to 12) averaged across all replicates, all days of analysis, frozen and refrigerated stored samples, for each laboratory (1 and 2), for skim milk and whole milk sets. For skim milk set, the regression equations for laboratory 1 and 2 are as follows: $\mathrm{y}=-1.68 \mathrm{x}+5.85$ and $\mathrm{y}=1.68 \mathrm{x}-5.85$, respectively. For whole milk set, the regression equations for laboratory 1 and 2 are as follows: $\mathrm{y}=0.14 \mathrm{x}+0.28$ and $\mathrm{y}=-0.14 \mathrm{x}-0.28$, respectively. As in experiment 1 , the regression equations indicate that the difference in the regression slope for both the skim and whole milk sets between the 2 laboratories was due to the slope setting of the instrument being used in the calibration equation. The use of frozen and thawed milk SCC standards may be feasible because no large differences in milk ESCC due to freezing and thawing were observed (Table 3). The results achieved in this experiment are 
in agreement with previous research that analyzed the effect of refrigerated and $7 \mathrm{~d}$ frozen storage conditions on SCC of bronopol preserved samples (Malinowski et al., 2008).

\section{CONCLUSIONS}

Gravity separation was an effective approach to isolate and concentrate normal somatic cells from bovine milk and redistribute them in a skim or whole milk matrix to create a set of reference materials for somatic cell counting with a wider and more uniformly distributed range of SCC than current calibration sets. The liquid SCC reference materials stored at $4^{\circ} \mathrm{C}$ were relatively stable (i.e., fit for purpose) for a 2 -wk period, whereas frozen and thawed reference materials may have a much longer use life. A gradual decrease occurred in residual difference in $\mathrm{ESCC}(\mathrm{SCC} \times 1,000 /$ $\mathrm{mL}$ ) versus original assigned reference SCC over time of refrigerated storage for both skim and whole milk SCC samples, indicating that milk ESCC of the preserved milks was gradually decreasing during $28 \mathrm{~d}$ of storage at $4^{\circ} \mathrm{C}$ by about $15,000 \mathrm{SCC} / \mathrm{mL}$. No difference $(P>$ 0.05 ) in the ESCC for skim milk was detected between refrigerated and frozen storage, whereas for whole milk the ESCC for frozen was lower $(P<0.05)$ than refrigerated samples. Future work is needed to determine the time and temperature of longer term frozen storage over which the SCC results are stable. The success of this approach will depend on maintaining the samples in a frozen state during delivery to laboratories and acceptance of the approach by regulatory agencies.

\section{ACKNOWLEDGMENTS}

The authors thank the USDA Federal Milk Markets (Carrollton, TX) for partial funding of this research. The authors thank the USDA Federal Milk Markets laboratories of Chicago, Illinois, and Dallas, Texas, and also the laboratory DairyOne (Ithaca, NY), for their collaboration. The authors thank the following staff members of Cornell University (Ithaca, NY): Jessica Podoll, Michelle Bilotta, Sara Bova, and Chassidy Coon, for technical assistance.

\section{REFERENCES}

Adams, M. C., and D. M. Barbano. 2015. Detection of differences in fat and protein test values among mid-infrared spectrophotometers using a novel statistical approach. J. Dairy Sci. 98:4174-4181.

AOAC International. 2000. Official Methods of Analysis. 17th ed. AOAC International, Arlington, VA.

Barbano, D. M., K. L. Wojciechowski, and J. M. Lynch. 2010. Effect of preservatives on the accuracy of mid-infrared milk component testing. J. Dairy Sci. 93:6000-6011.
Caplan, Z., C. Melilli, and D. M. Barbano. 2013. Gravity separation of fat, somatic cells, and bacteria in raw and pasteurized milk. J. Dairy Sci. 96:2011-2019.

Code of Federal Regulations. 2015. Title 7: Agriculture. Part 1000: General Provisions of Federal Milk Marketing Orders. Subpart G: Class Prices. Accessed Oct. 31, 2015. http://www.ecfr.gov/cgibin/text-idx?SID=dda045d0c9d37aa3abcbbd3bc6bf12ad\&mc=tru e\&node=se7.9.1000_150\&rgn=div8.

Craven, N., and M. R. Williams. 1985. Defences of the bovine mammary gland against infections and prospects for their enhancement. Vet. Immunol. Immunopathol. 10:71-127.

EUR-Lex. 2004. B Regulation (EC) No 853/2004 of the European Parliament and of the Council of 29 April 2004 laying down specific hygiene rules for food of animal origin. Accessed Oct. 31 2015. http://eur-lex.europa.eu/LexUriServ/\%20LexUriServ.do?uri $=$ CONSLEG:2004R0853:20071114:EN:PDF.

European Commission. 2011. Evaluation of CAP measures applied to the dairy sector. Accessed Oct. 31, 2015. http://ec.europa.eu/ agriculture/eval/reports/dairy/leaflet_en.pdf.

FDA. 2013. Grade "A" Pasteurized Milk Ordinance, 2013 revision. Accessed Oct. 31, 2015. http://www.fda.gov/downloads/Food/ GuidanceRegulation/UCM209789.pdf.

Fitts, J. E., and D. Laird. 2004. Direct microscopic methods for bacteria or somatic cells. Pages 269-280 in Standard Methods for the Examination of Dairy Products. 17th ed. H. M. Wehr and J. F. Frank, ed. Am. Public Health Assoc., Washington, DC.

Geer, S. R., and D. M. Barbano. 2014a. Effect of colostrum on gravity separation of milk somatic cells in skim milk. J. Dairy Sci. 97:687-693.

Geer, S. R., and D. M. Barbano. 2014b. The effect of immunoglobulins and somatic cells on the gravity separation of fat, bacteria, and spores in pasteurized whole milk. J. Dairy Sci. 97:2027-2038.

Glantz, S. A., and B. K. Slinker. 2001. Multicollinearity and what to do about it. Pages 185-211 in Primer of Applied Regression and Analysis of Variance. 2nd ed. McGraw-Hill Inc., New York, NY.

Halasa, T., K. Huijps, O. Østerås, and H. Hogeveen. 2007. Economic effects of bovine mastitis and mastitis management: A review. Vet. Q. 29:18-31.

Harmon, R. J. 1994. Physiology of mastitis and factors affecting somatic cell counts. J. Dairy Sci. 77:2103-2112.

IDF. 2013. Requirements for Reference Materials for the Calibration of Automated Somatic Cell Counters. Bulletin no. 469. International Dairy Federation, Brussels, Belgium.

IDFA. 2013. Food Safety Modernization Act: Current Good Manufacturing Practice and Risk-Based Preventive Controls Human Food. Accessed Oct. 31, 2015. http://www.idfa.org/docs/default-source/ fsma-comments/pmo-comments-111413.pdf?sfvrsn $=2$.

Jain, N. C. 1979. Common mammary pathogens and factors in infection and mastitis. J. Dairy Sci. 62:128-134.

Kaylegian, K. E., G. E. Houghton, J. M. Lynch, J. R. Fleming, and D. M. Barbano. 2006. Calibration of infrared milk analyzers: Modified milk versus producer milk. J. Dairy Sci. 89:2817-2832.

Madsen, P. S. 1975. Fluoro-opto-electronic cell-counting on milk. J. Dairy Res. 42:227-239.

Malinowski, E., S. Smulski, M. Gehrke, A. Klossowska, A. Arczynska, and M. Kaczmarowski. 2008. Effect of storage conditions and preservation with bronopol on SCC in cow milk. Med. Welt 64:1299-1303.

Mattern, C. F., F. S. Brackett, and B. J. Olson. 1957. Determination of number and size of particles by electrical gating: Blood cells. J. Appl. Physiol. 10:56-70.

National Mastitis Council. 2001. Guidelines on normal and abnormal raw milk based on somatic cell counts and signs of clinical mastitis. Accessed Oct. 31, 2015. http://nmconline.org/docs/abnmilk.pdf.

NDHIA. 2002. National Dairy Herd Improvement Program Uniform Operating Procedures. Accessed Oct. 31, 2015. http://www.dhia. org/uop.pdf.

NDHIA. 2013. About us. Objectives, Goals and Priorities of the Association. Accessed Oct. 31, 2015. http://www.dhia.org/objectives. asp. 
NDHIA. 2014. DHI Glossary. Dairy Records Management Systems. Accessed Jun. 8, 2016. http://www.ohs.rcs.k12.tn.us/TEACH$\mathrm{ERS} / \mathrm{marshallj} /$ website/CDE/Dairy/glossary.pdf.

Orlandini, S. 2012. International survey on somatic cell counting-Situation of lab network organization and practices. Pages 13-24 in ICAR Technical Series No. 16. International Strategies and New Developments in Milk Analysis. VI ICAR Reference Laboratory Network Meeting, Cork, Ireland.

Prescott, S. C., and R. S. Breed. 1910. The determination of the number of body cells in milk by a direct method. Am. J. Public Hygiene 20:633-664.

Read, R. B., A. L. Reyes, J. G. Bradshaw, and J. T. Peeler. 1967. Electronic counting of somatic cells in milk. J. Dairy Sci. 50:669-674.

Schalm, O. W., and B. S. Noorlander. 1957. Experiments and observations leading to development of the California Mastitis Test. J. Am. Vet. Med. Assoc. 130:199-204.

Schmidt-Madsen, P. 1975. Fluoro-opto-electronic cell-counting on milk. J. Dairy Res. 42:227-239.

Schneider, R., and D. E. Jasper. 1964. Standardization of the California Mastitis Test. Am. J. Vet. Res. 25:1635-1641.

Schukken, Y., D. Wilson, F. Welcome, L. Garrison-Tikofsky, and R. Gonzalez. 2003. Monitoring udder health and milk quality using somatic cell counts. Vet. Res. 34:579-596.
Silveira, T. M. L., L. M. Fonseca, T. B. N. Lago, and D. R. Veiga. 2005. Comparison between standard method and electronic analyses for measurement of the bovine milk somatic cell count. Braz. J. Vet. Res. Anim. Sci. 57:128-132.

Thompson, D. I., and D. S. Postle. 1964. The Wisconsin Mastitis Test-An indirect estimation of leucocytes in milk. J. Milk Food Technol. 27:271-275.

USDA. 2009. Marketing Service Bulletin. What is a federal marketing milk order, and... What does it mean to me? Accessed Oct. 31, 2015. http://www.fmmacentral.com/PDFdata/msb200906.pdf.

USDA. 2011a. Marketing Service Bulletin. Producer Milk Somatic Cell Counts. Accessed Feb. 11, 2015. http://www.fmmacentral.com/ PDFdata/msb201103.pdf.

USDA. 2011b. Notice to the industry. European Health Certification Program. Accessed Nov. 2, 2015. http://www.ams.usda. gov/sites/default/files/media/Official\%20EU\%20Health\%20 Certification\%20Program\%20document.pdf.

USDA. 2013. Marketing Service Bulletin. Calculating a "Pay Price." Accessed Feb. 11, 2015. http://www.fmmacentral.com/PDFdata/ msb201308.pdf.

van Asseldonk, M. A. P. M., R. J. Renes, T. J. G. M. Lam, and H. Hogeveen. 2010. Awareness and perceived value of economic information in controlling somatic cell count. Vet. Rec. 166:263-267. 